\title{
Internal Locus of Control, Task, and Contextual Performance in Multinational
}

\section{Organisations}

* Dr. Bilal Anwar, Assistant Professor

** Dr. Muhammad Zia-Ur-Rehman, Associate Professor (Corresponding Author)

*** Riaz Hussain Ansari, Lecturer

\begin{abstract}
The study investigates the association of employees' internal locus of control, employees' contextual and task performance. Survey questionnaires were gathered from middle-level managers from the banking sector of Pakistan. Regressions analysis was utilized to inspect the impacts of internal locus of control on two dimensions of employees' performance. Results demonstrate that middle-level managers internal locus of control emphatically impact task performance; internal locus of control uncovers a negative impact on employees' contextual performance. Besides, a person possessing an internal locus of control may experience a higher positive impact on employee task performance.

Keywords: Internal Locus of control, Task Performance, Contextual Performance, Middle-Level Managers

\section{Introduction}

Organizations overall are trying accomplishment and out-battle those in a similar business. To do all things considered, organizations need to get and utilize their workers effectively. Organizations should think about-face even more sensibly towards keeping awake with the most recent. As such, managers need to give cautious thought to all the middle components of representatives lead, perspective at the workplace as this expects a basic part in various authoritative, social, and monetarily related domains among others that are powerful to the achievement of the hierarchical targets and consequently organizations successful continuation in the business area. This concentrate, consequently, proceeds to discuss one of the middle components of workers which are a locus of control, representative execution, and how the earlier impacts the ongoing.

The Locus of Control (LOC) is related to the apparent wellspring of impact over our conduct and it is the apparent control that one may have on the circumstances around. "The locus of control idea expresses that work conduct can be clarified whether employees see results as controlled inside or remotely" (Wheatley, Armstrong, \& Maddox, 1989,). This component speaks to convictions about circumstances and results throughout one's life (Rotter 1966). People with an internal LOC see more noteworthy control, while external LOC see that destiny or intense others apply extraordinary impact on such occasions (Brown \& Trevino 2006). Internal-external LOC alludes to a singular's convictions that she or he has control over occasions (Ritchie \& Phares, 1969; Rotter, 1975; Terborg, 1985), Naik, 2015. Execution of a specialist at his/her workplace is a condition of compassion for all of the associations paying little heed to the significant number of factors and conditions. Therefore the laborers are believed to be a basic asset for their associations (Qureshi \& Ramay 2006). Internals LOC tend to be more fulfilled to be more remembered for their occupations appeared differently concerning facades LOC (Pretorius 2004).
\end{abstract}

\section{Objectives of the Study}

The following are the research objectives:

1. To check the role of locus of control

2. To find out the role of task performance in organizations

3. To find out the significance of contextual performance

\footnotetext{
* Department of Business Administration, University of Sahiwal Email: drbilalanwar@uosahiwal.edu.pk

** Department of Leadership and Management Studies, National Defense University

Email: drziaofficial@gmail.com

*** Department of Business Administration, University of Sahiwal
} 
4. To test the impact of locus of control in task and contextual performance

\section{Literature Review}

\section{Internal Locus of Control}

It is considered that the internal locus of control is a conviction that one is accountable for the occasions that happen in life. People possessing an interior locus of control trust their skills, knowledge, and abilities and they are guided by their will power and decisions. Thus they attempt and have authority over those things they can change in the environment or the circumstances. Having an inner locus of control is associated with self-feasibility, the conviction you have about having the ability to achieve something adequately. "A pioneer with an inward locus of control is inclined to be upheld by people colleagues. One explanation is that an "inward" individual is viewed as more successful than an "outside" individual considering the way that the person expects an obligation for happenings. The pioneer with an inside locus of control can underline that the person may alter horrible conditions" (Dubrin, 2010). "There is likewise confirming that internals are better ready to handle complex data and critical thinking, and that they are more accomplishment arranged than external (locus of control). What's more, individuals with a high internal locus of control are more probable than external to attempt to impact others (Daft, 2008).

Internal LOC people likewise tend to have higher accomplishment inspiration, be more deliberate and objective coordinated, be more outgoing, friendly, dynamic, and less psychotic and closed-minded than external (Ormel, \& Schaufeli, 1991). Those with an internal locus of control additionally tend to set all the more difficult objectives, persevere even with difficulty, encounter less occupation push, and be more fruitful by and large (Ng et al. 2006; Wang et al. 2010). It is nothing unexpected then that having an internal locus of control has been connected with higher income (e.g. Heineck and Anger 2010; Piatek \& Pinger 2010; Semykina \& Linz 2007; Osborne Groves 2005; Osborne 2000; Duncan \& Dunifon 1998; Andrisani 1981), speedier income development (Schnitzlein \& Stephani 2013), and more prominent occupation fulfillment (Ng et al. 2006).

\section{Task Performance}

Supporters who trust they are consummately fit for performing an errand are not as well-suited to be inspired by, or as ready to acknowledge, a mandate pioneer as they would a pioneer who shows participative practices" (Hughes, Ginnett, \& Curphy, 2012). Afshan et al. (2012) characterize task performance as the accomplishment of particular undertakings measured against foreordained or distinguished norms of exactness, culmination, cost, and speed. Griffin. Neal, \& Parker (2007) stated task performance identified with individual undertaking capability.

\section{Contextual Performance}

Contextual performance rehearses that the lifestyle of individuals should possess some air of the association, wherein change and upkeep practices are finished. Chipping in for extra work, suffering from energy, offering and teaming up with others, some help with following precepts and system, and supporting or protecting the association are altogether tests of logical execution rehearses (Motowidlo \& Schmit, 1999). The possibility of logical execution is skirting on undefined with Organ's hierarchical citizenship rehearses (Organ 1997). Habitually it isn't sufficient to consent to the proper occupation essentials; one has to go past what is officially required (Parker et al., 2006; Sonnentag \& Frese, 2002).

\section{Relationship of Employees Internal Locus of Control and Performance}

Two obvious purposes can be there to perform ideally at work over facades are given by Spector (1982). Right off the bat, internals (which means internal local of control) hold more grounded expectations that effort will achieve extraordinary execution and that incredible execution will incite prizes. In conditions where prizes take after incredible execution internals apply more conspicuous effort. Furthermore, internals search for new and relevant information all the more adequately and in this manner perform better than anything facades on complex endeavors which, subsequently, should provoke better execution by internals when complex information and learning are incorporated. But a couple of various investigations (Heisler, 1974; Valecha, 1972; Andrisani \& Nestel, 1976), uphold the above association, Spector (1982) alerts that it should be recollected that the better exhibition of internals may be pertinent for conditions where they see that effort will provoke regarded prizes. Spector (2002) found that individuals with an interior LOC presentation appear to be more prodded, perform better grinding away, and express bigger sums than individuals with an outer locus of control. 


\section{Theoretical Framework}

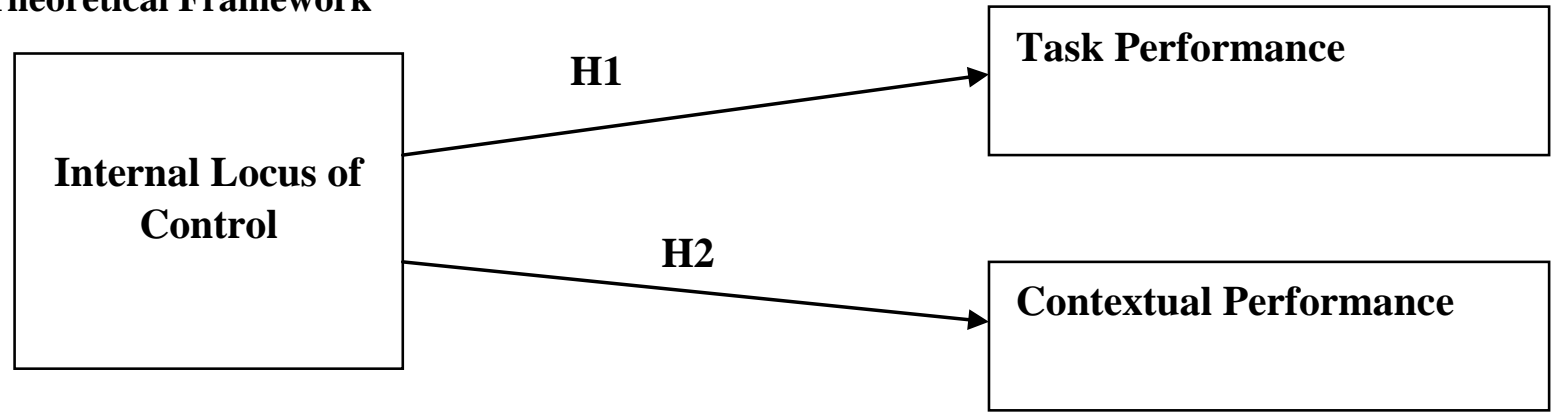

H1: There is a significant positive relationship between employee internal LOC and employee task performance.

H2: Internal Locus of Control and employee contextual performance has an effective relationship.

\section{Research Methodology}

The article and its research fall into the class of descriptive research as it endeavors to distinguish associations among employees' internal locus of control and employees' task and contextual performance. Consequently, the descriptive method to deal with research configuration would be embraced for the study. As per the State Bank Pakistan reports (2014), right now, there are above seven thousand bank branches working in Pakistan. Keeping in mind the end goal to prompt a more successful questionnaire survey, the subjects were reached by telephone and the survey questionnaires were sent to them exclusively. Stamped tended to envelopes were appended for questionnaire return. The questionnaires were disseminated and collect the subsequent two day's visits. We issued 300 and got 205 questionnaires. After disposing of 85 questionnaires with some blank responses and inadequate essential data, we gained 205 substantial questionnaires, a legitimate reaction rate of $68 \%$. Information was then dissected by utilizing SPSS 22.00. Regression analysis is additionally done to demonstrate the hypothesis. The expository apparatus to be utilized for this study was frequency distribution and percentages. That is, the quantities of the respondents of every inquiry tried in the hypotheses were processed and their rates were computed.

\section{Data Analysis Methods}

The first part of the study measures the employee's internal locus of control that depends on Spector (1988), who recommended that internal locus of control people perceive their offer of obligation in their victories and disappointments, there are four questions modified from Work Locus of Control Scale (WLCS) of Spector (1988). The measurement depended on a Likert 5-point scale, where 1 was "strongly disagree" and 5 was "strongly agree." A higher score shows that the members are well on the way to have an internal locus of control. Williams and Anderson (1991) develop a scale to measure employee task performance. Task performance scale having five items was utilized as the scale is evaluated on five Likert scale frame $1=$ strongly disagree to $5=$ strongly agree. Contextual performance was measured utilizing a 16-items instrument created by Motowidlo and Van Scotter (1994) for their studies intended to recognize tasks from contextual performance. For instance, questions requested that a manager rate how likely a worker is to "collaborate with others in the group" or "volunteer for extra work". Managers evaluated every member on a 5-point scale $(1=$ not at all likely; $5=$ to a great degree likely). 16 items scale used to measure employee contextual performance.

\section{Results and Discussion \\ Frequencies Analysis}

Purposive random sampling was chosen for this research to collect data from the banking sector of Pakistan. The survey questionnaire was finished by 205 employees. The response rate was therefore $68 \%$. Biographical information was accumulated in this study on the employees' gender, age, material status, qualification, and experience. The sample will now be depicted in (Table 5,6,7,8 and 9) terms of each of these variables. The results demonstrate more than half of the sample $(53.7 \%)$ was female while the rest $(47.3 \%)$ are male. A large number of the respondents that is, $(47 \%)$ have matured between 26-30 years. Of the total sample, 100 were married and 105 were unmarried. $62 \%$ of employees were master degree holders. A considerable bit of participants have one to five years' work experience. 
Table 1 Reliability of the variables

\begin{tabular}{lll}
\hline Variables & No. of Items & Cronbach Alpha \\
\hline Internal LOC & 4 & 0.739 \\
Task Performance & 5 & 0.819 \\
Contextual Performance & 16 & 0.757 \\
\hline
\end{tabular}

Table 2 Correlations

\begin{tabular}{llll}
\hline Correlations & & & \\
\hline & Internal_LOC & Emp_TP & Emp_CP \\
Internal_LOC & 1 & & \\
Emp_TP & $.985^{* *}$ & 1 & \\
Emp_CP & $-.202^{* *}$ & $-.201^{* *}$ & 1 \\
$* *$ Correlation is significant at the 0.01 level (2-tailed). & &
\end{tabular}

Based on the analysis, we can see that the reliabilities of both the independent and dependent variables are shown in table 1 which are $0.739,0.819$, and 0.757 as shown in table 2 the association of internal LOC, and task performance are show is highly positive correlated at the significance level of P .01 that is correlation is highly significant. And the relationship between internal LOC and contextual performance is show is negatively correlated at a significance level of $\mathrm{P} .01$ that is correlation is non-significant.

Table : 3 Model Summary of Internal LOC and Employees Task Performance

\begin{tabular}{|c|c|c|c|c|c|c|c|c|c|}
\hline \multirow[b]{2}{*}{ Model } & \multirow[b]{2}{*}{$\mathrm{R}$} & \multirow[b]{2}{*}{ R Square } & \multirow[b]{2}{*}{$\begin{array}{l}\text { Adjusted } \mathrm{R} \\
\text { Square }\end{array}$} & \multirow{2}{*}{$\begin{array}{l}\text { Std. } \\
\text { Error of } \\
\text { the } \\
\text { Estimate }\end{array}$} & \multicolumn{3}{|c|}{ Change Statistics } & \multirow[b]{2}{*}{ df2 } & \multirow[b]{2}{*}{$\begin{array}{l}\text { Sig. I } \\
\text { Change }\end{array}$} \\
\hline & & & & & $\begin{array}{l}\mathrm{R} \text { Square } \\
\text { Change }\end{array}$ & F Change & df1 & & \\
\hline 1 & $0.985^{\mathrm{a}}$ & 0.97 & 0.97 & 0.13713 & 0.97 & 6612.389 & 1 & 203 & 0 \\
\hline \multirow[t]{2}{*}{ Model } & & & $\begin{array}{l}\text { Unstandardi } \\
\text { zed } \\
\text { Coefficients } \\
\text { Beta Value }\end{array}$ & \multicolumn{2}{|c|}{$\begin{array}{l}\text { Standardized } \\
\text { Coefficients } \\
\text { Beta Value }\end{array}$} & \multicolumn{2}{|l|}{$\mathrm{t}$ Value } & & Sig. T \\
\hline & $\begin{array}{l}\text { (Const } \\
\text { Intern: }\end{array}$ & & $\begin{array}{c}-0.43 \\
1.003\end{array}$ & 0.985 & & $\begin{array}{l}-0.908 \\
81.317\end{array}$ & & & $\begin{array}{l}0.365 \\
0\end{array}$ \\
\hline
\end{tabular}

a. Predictors: (Constant), Internal_LOC

b. Dependent Variable: Emp_TP

In table 3, we can see that the estimation of beta value is 0.985 which shows $98 \%$ infers that for every one percent extension in inner LOC may have an impact of $98 \%$ effect on representative errand execution which is positive identified with inward LOC. All in all $98 \%$ of representative undertaking execution is being influenced by inward LOC and the staying by different components. Relapse investigation exhibits that connection between inside LOC and worker task execution is shown the estimation of $\mathrm{R}$ square 0.970 it exhibits that the impact of interior LOC on representative errand execution is $97 \%$ is explained. The explanation behind this investigation was to sort out the connection between the inward LOC and representative assignment execution of the banking area in Pakistan. According to the hypothesis, internal LOC had a positive relationship with employee task performance that how internal LOC impacts the performance of employees positively, the consequences of the correlation in table 2 likewise indicates both internal LOC and employee task performance is positively correlated.

Table: 4 Model Summary of Internal LOC and Employees Contextual Performance

\begin{tabular}{|c|c|c|c|c|c|c|c|c|c|c|}
\hline \multirow[b]{2}{*}{ Model } & \multirow[b]{2}{*}{$\mathrm{R}$} & \multirow[b]{2}{*}{$\begin{array}{l}\mathrm{R} \\
\text { Square }\end{array}$} & \multirow[b]{2}{*}{$\begin{array}{l}\text { Adjusted } \\
\text { Square }\end{array}$} & \multirow[b]{2}{*}{$\mathrm{R}$} & \multirow{2}{*}{$\begin{array}{l}\text { Std. } \\
\text { Error of } \\
\text { the } \\
\text { Estimate }\end{array}$} & \multicolumn{2}{|c|}{ Change Statistics } & \multirow[b]{2}{*}{ df1 } & \multirow[b]{2}{*}{ df2 } & \multirow[b]{2}{*}{$\begin{array}{l}\text { Sig. } F \\
\text { Change }\end{array}$} \\
\hline & & & & & & $\begin{array}{l}\mathrm{R} \\
\text { Square } \\
\text { Change }\end{array}$ & $\begin{array}{l}\text { F } \\
\text { Change }\end{array}$ & & & \\
\hline 1 & $0.202^{\mathrm{a}}$ & 0.041 & 0.036 & & 0.41198 & 0.041 & 8.655 & 1 & 203 & 0.004 \\
\hline \multirow[t]{3}{*}{ Model } & & & $\begin{array}{l}\text { Unstandardized } \\
\text { Coefficients } \\
\text { Beta Value }\end{array}$ & & $\begin{array}{l}\text { Standardiz } \\
\text { Coefficient } \\
\text { Beta Value }\end{array}$ & & \multicolumn{3}{|l|}{ t Value } & Sig. T \\
\hline & \multicolumn{2}{|c|}{ (Constant) } & 3.971 & & & & \multicolumn{3}{|l|}{28.232} & 0 \\
\hline & \multicolumn{2}{|c|}{ Internal LOC } & -0.109 & & -0.202 & & -2.942 & & & 0.004 \\
\hline
\end{tabular}


a. Predictors: (Constant), Internal_LOC

b. Dependent Variable: Emp_CP

In table 4 we can see that the estimation of beta value - 0.202 that shows 20.2 infers that for every one percent development in inner LOC will have an effect of 20.2 effects on worker logical execution which is associated contrarily to inward LOC. All in all 20.2 of representative relevant execution is being influenced by inner LOC and the staying by various parts. Relapse examination exhibits that connection between inside LOC and representative relevant execution is shown the estimation of R square 0.041 it shows that the impact of inner LOC on worker logical execution is $4.1 \%$ is explained. The relationship brings about table 2 likewise shows both inward LOC and worker logical execution is associated unfavorably.

In this research paper, the representatives do their employment reliably anyway because of the remaining burdens and time necessities their presentation decreases. Banks timing is generally from 9 am to $5 \mathrm{pm}$ in Pakistan anyway at first there is no time limit so representatives need to work for additional hours when contrasted with various occupations hitch is likewise an explanation of concern. The investigation was driven just in an industry that was financial area and the impact interior LOC on representative's task execution and logical execution was estimated just in one area, on the off chance that we need to sum up the results of this examination; at that point this exploration should be recreated in various area of Pakistan moreover.

\section{Conclusion and Recommendations}

Knowing whether workers have an internal or external locus of control characteristics is valuable in offering them some assistance with developing. For instance, personality management workshops would be valuable, by offering external assistance with building up better adapting aptitudes, to emphatically influence employees performance and maintenance levels inside of the organization. Picking up knowledge into one's identity attributes can prompt positive changes at play and work. Internals are seen to apply more noteworthy exertion with the desire that more prominent performance prompts prize, show more professional achievement, and perform better inside of the organization.

It is clear from the findings part that the internal LOC assumes an important part in employees' task performance and on the powerful utilization of aptitude and information of the specialists. Employees are the key achievement component in the service sector like banks were staying aggressive relies on employee's performance (Khan, et.al., 2011; Lawler \& Siengthai, 1997; Moyeen \& Huq, 2001). For higher performance, employee's task performance and contextual performance are significant which can be guaranteed through identification of LOC. In the competitive environment, employees of any business organizations are the key variable for deciding the achievement of the bank. At the point when banks don't focus on employees' performance because of expenses decrease, those banks must experience the effects of budgetary issues. In Pakistan, banks used to disregard concentrating on the need of employees for a drawn-out period, yet now employees are a major concern for the banks. As Customer Relationship Management (CRM) is getting importance in commercial banks, the employees must be conferred towards the service delivery where employees' contextual performance is just as imperative. At the last, it is recognized this study has some impediments because of the time accessibility of the respondents. It was unrealistic to consolidate a colossal overview and take a major sample size, as some of the bank managers were hesitant to respond due to the secrecy and occupied work hours. Hence, more exceptional research is required in this developing sector.

\section{References}

Afshan, S., Sobia, I., Kamran, A. \& Nasir, M. (2012). Impact of training on employee performance: a study of the telecommunication sector in Pakistan. Interdisciplinary Journal of Contemporary Research in Business, 4, (6).

Andrisani P (1981) internal-external attitudes, sense of efficacy, and labor market experience: A reply to Duncan and Morgan. Journal Human Resource, 16:658-666.

Asgari, M., \& Vakili, M. (2012). The Relationship between Locus of Control, Creativity, and Performance of the Educational Department Employees in the west of Mazandaran. International Research Journal of Applied and Basic Sciences. 3(S), 2556-2561.

Daft, R. L. (2008). The leadership experience (4th ed.). Mason: OH: Thomson/South-Western.

Donatelle, R. (2011). Health: The basics (Green ed.). San Francisco: Pearson Benjamin Cummings. 
Dubrin, A. J. (2010). Leadership: Research findings, practice, and skills(6th ed.). Mason, OH: SouthWestern/Cengage Learning.

Duncan GJ, Dunifon R (1998) Soft skills and long-run labor market success. In: Polachek S (ed) Research in Labor Economics. JAI Press, Stamford, Conn, 123-129.

Griffin, M. A., Neal, A \& Parker, S. K. (2007) 'A new model of work role performance: Positive behavior in uncertain and interdependent contexts', Academy of Management Journal, 50: 327-347.

Heineck G, Anger S (2010) The returns to cognitive abilities and personality traits in Germany. Labor Economics, 17:535-546.

Hughes, R. L., Ginnett, R. C., \& Curphy, G. J. (2012). Leadership: Enhancing the lessons of experience (7th ed.). New York: McGraw-Hill/Irwin.

$\mathrm{Ng}$ TWH, Sorensen KL, Eby LT (2006) Locus of control at work: A meta-analysis. Journal Organizational Behavior, 27(8):1057-1087.

Northouse, P. G. (2013). Leadership: Theory and practice (6th ed.). Thousand Oaks, CA: Sage.

OrmeL J., \&Schaufeli, W. (1991). Stability and change in psychological distress and their relationship with self-esteem and locus of control. Journal of Personality and Social Psychology, 60, 288299.

Osborne Groves M (2005) how important is your personality? The labor market returns to personality for women in the US and UK. Journal of Economic Psychology, 26:827-841.

Piatek R, Pinger P (2010) Maintaining (locus of) control? Assessing the impact of locus of control on education decisions and wages. IZA Discussion Paper 5289, available at http://ftp.iza.org/dp5289.pdf

Pretorius., W. (2004). Locus of control. Available at: http://www.upetd.up.ac.za/thesis/available /ed03162004-13162004-131828/unrestricted/05chatpers.pdf

Ritchie, E., \&Phares, E. J. (1969).Attitude change as a function of internal-external control and communicator status. Journal of Personality, 37, 429-443.

Rotter, J. B. (1975). Some problems and misconceptions related to the construct of internal versus external control of reinforcement. Journal of Consulting and Clinical Psychology, 43, 56-67.

Schnitzlein DD, Stephani J (2013) Locus of control and low-wage mobility. SOEP Working Paper 589, DIW, available at www.diw.de/documents/publikationen/73/diw 01.c.429214.de/ diw_sp0589.pdf

Semykina A, Linz SJ (2007) Gender differences in personality and earnings: Evidence from Russia. Journal of Economic Psychology, 28:387-410. doi: 10.1016/j.joep.2006.05.004

Spector, E. P. (2002). Locus of Control and Well-Being at Work: How Generalizable Are Western Findings? The Academy of Management Journal, 45, 453-466.

Terborg, J. R. (1985). Working women and stress. In T. A. Beehr\& R. S. Bhagat (Eds.), Human stress and cognition in organizations: An integrated perspective. New York: Wiley.

Wang Q, Bowling N, Eschleman KJ (2010) A meta-analytic examination of work and general locus of control. Journal Applied Psychology, 95(4):761-768. 